\title{
A Review Of The Clinical Outcomes In Idursulfase- Treated And Untreated Filipino Patients With Mucopolysaccharidosis Type II: Data From The Local Lysosomal Storage Disease Registry
}

Marie Julianne Castillo Racoma ( $\nabla$ mcracoma@up.edu.ph )

Philippine General Hospital https://orcid.org/0000-0003-0502-3191

Maria Kristina Karizza B. Calibag

Philippine General Hospital

\section{Mary Anne D. Chiong}

Institute of Human Genetics-National Institutes of Health

Mary Ann R. Abacan

Philippine General Hospital

Cynthia Cordero

University of the Philippines, Manila

\section{Research}

Keywords: Mucopolysaccharidosis Type II, Hunter syndrome, enzyme replacement therapy, idursulfase, rare disease, registry, Filipino

Posted Date: November 3rd, 2020

DOI: https://doi.org/10.21203/rs.3.rs-98874/v1

License: (c) (i) This work is licensed under a Creative Commons Attribution 4.0 International License. Read Full License

Version of Record: A version of this preprint was published at Orphanet Journal of Rare Diseases on July 21 st, 2021. See the published version at https://doi.org/10.1186/s13023-021-01875-5. 


\section{Abstract}

Background: Mucopolysaccharidosis type II (MPS II; Hunter syndrome) is an X-linked multisystem disorder characterized by glycosaminoglycan (GAG) accumulation, caused by a deficiency of iduronate-2-sulfatase (I2S). Enzyme replacement therapy (ERT) with recombinant I2S, the standard of care, was started in the Philippines in 2017. This study reviewed the clinical outcomes in idursulfase-treated and untreated Filipino MPS II patients who were included in the local Lysosomal Storage Disease (LSD) registry of the Institute of Human Genetics-National Institutes of Health (IHG-NIH) from January 1999 to December 2019.

Methods: A retrospective audit of records of MPS II patients listed in the registry was done. Qualified patients were divided into two cohorts: idursulfase-treated group (patients on enzyme replacement therapy, ERT, for $\geq 6$ months) and untreated group. Baseline characteristics, including demographic data, biochemical results, neurocognitive classification, respiratory involvement, mortality, and adverse events, were recorded. Height, weight, cardiac pathology, liver and spleen sizes, six-minute walk test (6MWT), joint mobility, were determined at baseline and at year 1 and 2 of follow up.

Results: Forty male patients were included in this review, with 8 receiving ERT since 2017 . The mean age at diagnosis was 6.99 years (SD 4.15; 0.75-20) and mean age at start of ERT was 14.03 years (SD 7.1; 4-21.5), more delayed than previous reports. Eighty percent have early progressive phenotype which was higher than reported average. The early growth pattern differed in our Filipino cohort, but was followed by the expected slowed growth in later years. Improvements in the following endpoints were observed in the treated cohort: height and weight, cardiac disease, liver and spleen sizes, and joint mobility. There were also positive effects on respiratory involvement and mortality rate. Adverse events were consistent with previous reports.

Conclusions: ERT is generally well tolerated and effective in reducing GAG storage and improving clinical endpoints among our Filipino MPS II patients. In untreated patients, typical disease progression was observed.

\section{Introduction}

Mucopolysaccharidosis type II (MPS II; also known as Hunter syndrome) is an X-linked multisystem disorder characterized by glycosaminoglycan (GAG) accumulation, caused by a deficiency of iduronate-2-sulfatase (I2S). ${ }^{1}$ The enzyme deficiency in MPS II leads to primary accumulation of dermatan sulfate (DS) and heparan sulfate (HS). ${ }^{2}$ The buildup of these GAGs accounts for heterogenous somatic and neurologic manifestations of the disease. $^{3}$

The clinical manifestations of MPS II, including age of onset, disease severity, and rate of progression vary significantly among affected males. Until recently, phenotypes are designated as "slowly progressive" or "early progressive", depending on the presence or absence of CNS involvement, respectively. In those with early progressive disease, there is progressive cognitive deterioration, progressive airway and cardiac disease that usually result in death in the first or second decade of life. While in those with slowly progressive disease, the CNS is minimally or is not affected, although the effect of GAG accumulation on other organ systems may be the same as in early progressive types. Other clinical features present in both phenotypes include: short stature, coarse facies, macrocephaly with or without communicating hydrocephalus; macroglossia; hoarse voice; conductive and sensorineural hearing loss; frequent sinus and ear infections, umbilical hernia, hepatosplenomegaly; dysostosis multiplex; spinal stenosis; joint contractures and carpal tunnel syndrome. ${ }^{1}$ 
A multidisciplinary approach to treatment and symptomatic care remain to be the most important aspects of MPS management. However, disease-modifying strategies are available and include enzyme replacement therapy (ERT) and hematopoietic stem cell transplantation (HSCT). ${ }^{2}$ Of the two, ERT with recombinant idursulfase (IDS) is currently the recommended treatment strategy that is used routinely in clinical practice. In order to assess the efficacy of treatment with IDS and to monitor the response to ERT, it has been suggested to continuously evaluate different clinical, laboratory, and instrumental endpoints that may include: urinary GAGs excretion, six-minute walk test (6MWT), forced vital capacity (FVC), liver and spleen volumes, and joint mobility. ${ }^{4}$ A series of studies have consistently demonstrated somatic improvements with ERT that consequently result in a better quality of life for some patients, ${ }^{5-8}$ as well as improved survival. ${ }^{9}$ Idursulfase has also been shown to be generally well tolerated, with a safety profile similar to that reported for ERT in patients with other mucopolysaccharidoses. ${ }^{1}$ The main limitation of therapy, however, is the inability of IDS to cross the blood-brain barrier rendering it ineffective against neurological symptoms. ${ }^{4}$

The global incidence of MPS II is 1:100,000-170,000 male births. Hunter syndrome is the most prevalent MPS in the Philippines, comprising around $84 \%,{ }^{10}$ similar in other East Asian regions. ${ }^{3,11}$ As of writing, 59 patients have been recorded in the Lysosomal Storage Disease (LSD) registry of the Institute of Human Genetics-National Institutes of Health (IHG-NIH), the only institution in the Philippines providing genetic services. The listing was started in 1999 to provide an updated census of Filipinos diagnosed with any of the LSDs that later evolved into a registry that included baseline information and outcomes of patients with these conditions. However, this registry

is limited to patients reported to the Philippine General Hospital (PGH) and/or IHG-NIH. This was patterned after the Hunter Outcome Survey (HOS), which was established in 2005, by a global scientific advisory board comprised of physicians experienced in MPS II. For rare diseases, a large, multicenter, observational registry is useful in collecting long-term data on the natural history of MPS II and the efficacy and safety of treatment from a broad population of patients. ${ }^{1}$

It has now been a more than a decade since ERT with intravenous IDS has been approved and used as standard of care. Locally, ERT for a limited number of Filipino patients was started in 2017. Though it is regarded as the standard of care, IDS is very expensive. It costs approximately Php 1 to 1.5 million per month to treat a 15 to $30 \mathrm{~kg}$ patient. It requires weekly injections causing a disruption in their everyday lives for patients and their caregivers. The aim of the study is to review the clinical outcomes of idursulfase-treated and untreated Filipino patients with MPS II who were included in the LSD Registry from January 1999 to December 2019. By looking at these outcomes, we could have a better understanding of its effects and safety among our Filipino cohort. Long-term follow up of these patients will also give a more comprehensive look into its disease progression.

\section{Methods}

This is a retrospective descriptive study of MPS II patients diagnosed at the Philippine General Hospital (PGH), University of the Philippines Manila (UPM) and/or at the IHG-NIH who were subsequently listed in the LSD Registry from January 1999 to December 2019. Waiver of informed consent was applied since the retrospective method of data collection would entail not more than minimal risk. The study protocol was approved by UPM Research Ethics Board (2020-108-01).

An audit of the records from the Registry was supplemented by patient charts and included only biochemicallyconfirmed MPS II cases with at least one follow-up at the PGH outpatient department, in-patient wards, or MPS 
multidisciplinary clinic. They were divided into two cohorts as follows: 1) idursulfase-treated group included patients who have been receiving ERT with recombinant IDS at $0.5 \mathrm{mg} / \mathrm{kg}$ administered weekly and continuously for at least 6 months and 2) Untreated group who have not received IDS at any point or have received ERT for less than 6 months.

Age at onset of symptoms, age at diagnosis, urinary GAG concentration at diagnosis, plasma enzyme assay level, age at treatment onset, length of time on treatment, cognitive impairment (diagnosed and classified at any time by a Developmental Pediatrician based on DSM V), respiratory disease, deceased, age at death, and cause of death were collected from the registry by the primary investigator.

\section{Clinical parameters}

Clinical parameters in the IDS-treated group were recorded at baseline and at year 1 and 2 of treatment. A postbaseline measurement was defined as the value recorded closest to the first and second year from treatment initiation, within 6 months either side of the date. For the untreated cohort, post-baseline measurement was defined as the value recorded closest to the first and second year from diagnosis, within 6 months either side of the date.

\section{Growth}

Since growth is age-dependent, data on height (in $\mathrm{cm}$ ) and weight (in kg), with corresponding z scores, and absolute change from baseline were stratified and analyzed within three age groups, with age 6 and 10 years old chosen as age cut offs at the start of ERT (for treated group) or age at diagnosis (for the untreated group) because growth tend to be faster during the early years, followed by slowed growth starting at 8 years and beyond. ${ }^{12}$

\section{Cardiac pathology}

Cardiac pathology, as evident on echocardiographic data, were recorded. The presence of left ventricular hypertrophy (LVH) was based on echocardiogram findings and defined by left ventricular mass index (LVMI) calculated as the left ventricular mass normalized for body surface area according to the recommendations of the American Society of Echocardiography (ASE). The diagnosis of LVH is attained when the LVMI is $\geq 102 \mathrm{~g} / \mathrm{m}^{2}$.

\section{Liver and Spleen Size}

Sizes were measured in $\mathrm{cm}$ by palpation according to standard clinical practice.

\section{Six-minute walk test (6MWT)}

This was measured in meters as the distance that the patient was able cover in six minutes.

\section{Joint mobility}

Joint range of motion (ROM) of shoulder, elbow, wrist, hip, knee and ankle mobility in degrees were recorded.

\section{Safety}

Safety profile was determined as the proportion of patients reported to have any adverse events (AEs) and recorded as either infusion-related reactions (IRR), defined as AEs assessed to be drug-related and occurring within 24 hours of the infusion, or not related (Non-IRR).

\section{Biochemical studies}


LSD assay for all 40 patients were sent to the laboratory of the Department of Medical Genetics, National Taiwan University Hospital. Confirmed cases are patients with either an enzyme activity measurement and/or quantitative urine GAGs. Plasma I2S activity was measured in using the 4-methylumbelliferone (4-MU) fluorometric enzyme assay. The concentration of urinary glycosaminoglycans was measured using the Dimethylene Blue (DMB) assay with results compared with the established reference ranges per age group of urinary GAGs per grams of creatinine.

\section{Data analysis}

Descriptive statistics were used to summarize demographic characteristics of the patients.

Categorical variables (presenting manifestations, respiratory symptoms, neurocognitive classification, cardiac disease, mortality, and adverse events) were summarized as proportions and frequency distributions were obtained. Continuous variables (height, weight, LVMI, extent of hepatosplenomegaly, 6MWT, joint ROM, and biochemical results) were summarized as means, standard deviation and range (minimum and maximum values). This was done separately for treated and untreated patients, at baseline, year 1, and year 2 of follow-up.

For height and weight, data was analyzed according to three groups based on the age at start of ERT or at time of diagnosis for the untreated group (Group 1: aged < 6 years, Group 2: 6-10 years, and Group 3: >10 years). Analysis was done at baseline, year 1 and 2 of follow up.

\section{Results}

As of December 2019, there were 59 Hunter syndrome patients listed in the Philippine LSD Registry, 40 of whom fulfilled the inclusion criteria. At the time of review, 27 of 40 patients are alive, eight of whom are on regular and continuous ERT with recombinant IDS (Elaprase ${ }^{\circledR}$, Shire Human Genetic Therapies, Inc., Cambridge, MA, USA).

\section{Demographic Characteristics}

A total of 40 male patients from 29 non-consanguineous families were included in this review. They were all of Filipino descent except for one patient under the treatment group who was adopted out of the family, born to a Filipina mother and a Caucasian father. The mean age at onset of symptoms was 2.28 years (SD 1.70; range 0.56). The average age at the time of diagnosis was 6.99 years (SD 4.15) with time to diagnosis of 0.75 of a year to as late as 20 years after onset of symptoms. Among the 27 patients who were still alive, their mean age was 13.6 years at the time of review (SD 6.4; range 4.42 to 30.33 ).

Among the 40 patients, 9 were initially started on ERT. However 1 patient withdrew after the 6th session following an anaphylactic reaction. Eight patients were classified under the treatment group as they continue to receive weekly ERT for at least 6 months. The mean age at the start of ERT was 14.03 years old (SD 7.1; 4-21.5), with mean delay of 9 years (SD 6.68; 0.25-20.66) from time of diagnosis to start of ERT. Since ERT was started in our country in 2017, the patients have been receiving weekly therapy for mean of 21.12 months (SD 8.7; 10-32) in duration.

The most common presenting manifestations in all patients were joint contractures in $12(30.77 \%)$ and recurrent respiratory tract infections in $11(28.2 \%)$ (Table 1$)$. 
Table 1

Presenting clinical manifestations among Filipino Hunter syndrome patients.

\begin{tabular}{|lll|}
\hline Presenting manifestation & Number $(\mathbf{n = 4 0})$ & Percentage \\
\hline Joint contractures & 12 & $30.77 \%$ \\
\hline Recurrent respiratory tract infections & 11 & $28.2 \%$ \\
\hline Coarse facies & 9 & $23 \%$ \\
\hline Developmental delay & 9 & $23 \%$ \\
\hline Inguinal hernia & 4 & $10.25 \%$ \\
\hline Hepatosplenomegaly and/or abdominal enlargement & 3 & $7.5 \%$ \\
\hline Short stature & 1 & $2.56 \%$ \\
\hline Note: Ten patients presented with 2 different symptoms and were counted separately. \\
\hline
\end{tabular}

\section{Clinical Outcomes}

\section{Height}

Eleven patients were classified under group 1 (treated $=2$ patients, mean age at starting ERT $=4.7$ years; untreated $=9$, mean age at diagnosis $=3.39$ years). The mean height at baseline was $100.55 \mathrm{~cm}$, ranging from $80-111 \mathrm{~cm}$ (SD 9.74). Only 1 patient was classified as stunted (WHO z score below - 2) at the onset, coming from the treated cohort. At the end of the 2-year follow up period, the mean height was $110.83 \mathrm{~cm}$ (SD 7.33; 104.4-130), with an overall increase in height by $10.28 \mathrm{~cm}$. Two patients from the untreated group were reclassified as stunted, bringing the total to $3(27.3 \%)$ stunted patients at end of year 2 .

Sixteen patients were classified under group 2. One patient was treated. ERT was started when the child was 10 years old. The child was stunted. For the 15 untreated patients, the mean age at diagnosis is 7.67 years, and the mean height at baseline was $109.34 \mathrm{~cm}$ (SD 9.37; 96-127). Eleven of the 16 (68.75\%) patients were considered stunted at the outset. At the end of year 2, only 10 patients have data. The mean height was $115.43 \mathrm{~cm}$ (SD 12.3; $99-134)$ with an overall increase in height by $3.23 \mathrm{~cm}$. The percentage of stunted patients (70\%) was comparable with baseline data

Thirteen patients were classified under group 3 (treated $=5$, mean age at starting ERT $=17$ years; untreated $=8$, mean age at diagnosis $=15.25$ years). The mean height at baseline was $116.68 \mathrm{~cm}$ (SD 13.91; 95-143.8). All 13 patients in this group were classified as stunted at the outset. After the 2-year follow up period, the mean height for all was $125.57 \mathrm{~cm}$ (SD 13.87; 110-144) with an overall increase in height by $5.59 \mathrm{~cm}$.

At the end of the 2-year follow up period, as observed in groups 1 and 3 (Fig. 1), there was a greater increase in height in the treated group compared to the untreated group, with higher height increase noted in the younger group (group 1) than in the older cohort (group 3). Further, none of the treated patients were shorter than their baseline height across all age-stratified groups (Fig. 2), as compared with the untreated group wherein 5 patients were recorded to be shorter by an average of $5.3 \mathrm{~cm}$ than their baseline height. As the patients increase in age, there was a notable increase in the percentage of stunted patients, to such an extent that all patients who initiated treatment or were diagnosed at age 10 years and above were stunted. 


\section{Weight}

The distribution of patients across the age-stratified groups were similar with the height data. In group 1 patients, mean weight at baseline was $18.86 \mathrm{~kg}$, ranging from 11.3 to $23.4 \mathrm{~kg}$ (SD 3.36). None of the patients were classified as underweight at the onset, (WHO z score below - 2). At the end of 2-year follow up period, the mean weight was $23.08 \mathrm{~kg}$ (SD 2,76; 20.5-30.3) with an overall increase in weight by $4.22 \mathrm{~kg}$. Only 1 out of 11 (9\%) patients was reclassified as underweight at end of year 2 , from the untreated cohort.

Sixteen patients were classified under group 2, and the mean weight at baseline was $22.26 \mathrm{~kg}$ (SD 3.86; 18-29.4). Three of the 16 (18.75\%) patients were considered underweight at the outset, including the only patient from the treatment group. At the end of year 2, only 10 untreated patients have data. The mean weight was $25.05 \mathrm{~kg}$ (SD $4,74 ; 16.7-33.18)$ with an overall increase in weight by $2 \mathrm{~kg}$. However there was a greater percentage (45.5\%) of underweight patients.

Thirteen patients were classified under group 3, and the mean weight at baseline was $28.26 \mathrm{~kg}$ (SD 7.13; 17.244.5). Eleven of the 13 (84.62\%) were classified as underweight at the outset. After the 2-year follow up period, the mean weight was $33.03(10.7 ; 17-50.8)$ with an overall increase in weight by $3.11 \mathrm{~kg}$. There was slightly greater percentage $(87.5 \%)$ of underweight patients overall, with all untreated patients being underweight by the end of year 2.

At the end of the 2-year follow up period, there was a greater interval increase in weight in the untreated cohort under group 1, but the reverse was seen in group 3 patients (Fig. 3). All treated patients experienced continued weight gain over the 2-year observation period, while 11 untreated patients had weight loss recorded at least once during their follow up (Fig. 4). Lastly, there was an increasing percentage of underweight patients annually in the untreated group, to such an extent that all patients in the oldest age group (group 3) were underweight at the end of year 1 and 2 .

\section{Neurocognitive classification}

Based on the recent classification according to phenotype, $80 \%$ of the patients (32/40) presented with early progressive course or severe. Twenty percent (8/40) fall under the slowly progressive, or attenuated, form of the disease, with only 1 patient with normal neurocognitive status, coming from the treated cohort. Among the 8 treated patients, 4 patients (50\%) have an early progressive form and the other half were assessed to have a slowly progressive course. Neurocognitive classification and their distribution are shown in Table 2. 
Table 2

Phenotypic classification according to severity and distribution according to developmental assessment and treatment group.

\begin{tabular}{|c|c|c|c|c|c|}
\hline & $\begin{array}{l}\text { Classification }(n= \\
40) \\
(\%)\end{array}$ & $\begin{array}{l}\text { Developmental } \\
\text { Assessment }\end{array}$ & $\begin{array}{l}\text { Treated }(\mathrm{n}= \\
8) \\
(\%)\end{array}$ & $\begin{array}{l}\text { Untreated }(n= \\
32) \\
(\%)\end{array}$ & $\begin{array}{l}\text { Total } \\
(n=40) \\
(\%)\end{array}$ \\
\hline \multirow[t]{4}{*}{$\begin{array}{l}\text { Early } \\
\text { Progressive }\end{array}$} & \multirow[t]{4}{*}{$\begin{array}{l}32 \\
(80 \%)\end{array}$} & GDD & $\begin{array}{l}2 \\
(25 \%)\end{array}$ & $6(18.75 \%)$ & $\begin{array}{l}8 \\
(20 \%)\end{array}$ \\
\hline & & ID, moderate & 0 & $\begin{array}{l}2 \\
(6.25 \%)\end{array}$ & $\begin{array}{l}2 \\
(5 \%)\end{array}$ \\
\hline & & ID, severe & 0 & $\begin{array}{l}8 \\
(25 \%)\end{array}$ & $\begin{array}{l}8 \\
(20 \%)\end{array}$ \\
\hline & & ID, unclassified & $\begin{array}{l}2 \\
(25 \%)\end{array}$ & $12(37.5 \%)$ & $\begin{array}{l}14 \\
(25 \%)\end{array}$ \\
\hline \multirow[t]{2}{*}{$\begin{array}{l}\text { Slowly } \\
\text { Progressive }\end{array}$} & \multirow[t]{2}{*}{$\begin{array}{l}8 \\
(20 \%)\end{array}$} & ID, mild & $\begin{array}{l}3 \\
(37.5 \%)\end{array}$ & $\begin{array}{l}4 \\
(12.5 \%)\end{array}$ & $\begin{array}{l}7 \\
(17.5 \%)\end{array}$ \\
\hline & & $\begin{array}{l}\text { No cognitive } \\
\text { impairment }\end{array}$ & $\begin{array}{l}1 \\
(12.5 \%)\end{array}$ & 0 & $\begin{array}{l}1 \\
(2.5)\end{array}$ \\
\hline
\end{tabular}

\section{Respiratory}

A total of $31 / 40$ patients $(77.5 \%)$ had respiratory involvement (Table 3 ). A greater percentage of untreated patients had respiratory symptoms $(81.25 \%)$ as compared with the treated cohort (62.5\%). The percentage of CPAPdependent patients are comparable in both cohorts. None of the treated patients necessitated tracheostomy thus far.

Table 3

Respiratory involvement and diagnosis among the treated and untreated cohorts.

\begin{tabular}{|llllll|}
\hline & $\begin{array}{l}\text { Respiratory } \\
\text { Involvement }\end{array}$ & $\begin{array}{l}\text { Bronchial } \\
\text { Asthma }\end{array}$ & OSA* & $\begin{array}{l}\text { CPAP } \\
\text { dependent }\end{array}$ & Tracheostomy \\
\hline Treated $(\mathbf{n = 8 )}$ & $5(62.5 \%)$ & $4(50 \%)$ & $4(50 \%)$ & $1(12.5 \%)$ & 0 \\
\hline $\begin{array}{l}\text { Untreated }(\mathbf{n}= \\
32)\end{array}$ & $26(81.25 \%)$ & $6(15 \%)$ & $\begin{array}{l}20 \\
(62.5 \%)\end{array}$ & $4(12.5 \%)$ & $2(12.5 \%)$ \\
\hline Total $(\mathbf{n}=40)$ & $31(77.5 \%)$ & $10(25 \%)$ & $24(60 \%)$ & $5(12.5 \%)$ & $2(5 \%)$ \\
\hline *OSA: obstructive sleep apnea & & & & \\
\hline
\end{tabular}

\section{Cardiac Disease}

Baseline cardiac data was available from 23 patients (treated $=4$, untreated $=19$ ). Majority $(15 / 23 ; 65.2 \%)$ had evidence of cardiac disease on 2D echocardiogram, including valvular disease in 13 (56.52\%) and/or chamber 
enlargement in 9 (39.13\%). The most commonly involved valves were the mitral and atrial valves; while the left ventricle and atrium were the most commonly enlarged chambers. At the end of the 2-year follow up period, data from 11 patients was available (treated $=3$, untreated $=8$ ), showing a greater percentage $(81.8 \%)$ of patients with cardiac involvement. However, following 2 years of therapy, there was an overall improvement in cardiac profiles of the treated cohort. Two of the $3(66.67 \%)$ patients had valvular involvement, compared to $100 \%$ involvement at baseline. In addition, in 2 treated siblings, there was improvement in their cardiac dimensions as both achieved normal chambers, consistent with decrease in their LVMI (mean decrease of $25 \mathrm{~g} / \mathrm{m}^{2}$ ). None of the treated patients were found to have cardiac hypertrophy after 2 years. While in the untreated cohort, the natural progression of cardiac disase was observed in the majority. Compared with baseline of $47.37 \%(9 / 19), 75 \%$ of patients $(6 / 8)$ had valvular involvement. At baseline, $36.84 \%$ of untreated patients $(7 / 19)$ had chamber enlargement, which increased to $75 \%(6 / 8)$ after 2 years. Among the untreated patients with complete data throughout the follow up period, 1 remained to have normal cardiac findings, 1 had further depression in systolic function with concomitant decrease in ejection fraction, 2 developed chamber enlargement, 1 had progression in both valvular disease and cardiac hypertrophy, and 3 had the same findings as baseline.

Mean LVMI for all at diagnosis was $92 \mathrm{~g} / \mathrm{m}^{2}$ (SD 26; 61-162). Overall, there was progression in the mean LVMI after 2 years to $115.17 \mathrm{~g} / \mathrm{m}^{2}$ (SD 26;61-162). However, this is largely coming from the untreated cohort wherein LVMI progressed to $147.33 \mathrm{~g} / \mathrm{m}^{2}$ (SD $56.15 ; 111-212$ ) after 2 years, in contrast to the mean LVMI for the treated cohort which improved to $83 \mathrm{~g} / \mathrm{m}^{2}$ (SD 12; 71-95, Fig. 5).

\section{Hepatosplenomegaly}

Among the 36 patients with baseline data, 21 (58.33\%) had liver enlargement with mean measurement of $4.79 \mathrm{~cm}$ below RCM (SD 2.4; 2-12). In the treatment group, 7/8 patients (87.5\%) had hepatomegaly (mean $4.43 \mathrm{~cm}$ below RCM), while $50 \%$ of the untreated cohort (14/28) had liver edge palpable up to mean of $4.96 \mathrm{~cm}$ from RCM. At the end of 2-year follow up, there was resolution of hepatomegaly in all treated patients ( 3 of which resolved after 1 year of therapy). In the untreated group, $15 / 16$ patients (93.75\%) remained to have hepatomegaly with mean of $4.78 \mathrm{~cm}$ below RCM. There was also progression in liver size by $4.71 \mathrm{~cm}$ from baseline noted in 9 untreated patients.

For spleen size, baseline data was available for 34 patients, with only 8 patients $(23.53 \%)$ presenting with splenomegaly with mean measurement of $4.44 \mathrm{~cm}$ below LCM. Two of the $8(25 \%)$ treated patients and $6 / 26$ $(23 \%)$ of untreated patients had baseline splenomegaly. After 1 year of ERT, there was resolution of splenomegaly in 1 treated patient, while the remaining patient's spleen was palpable up to $1 \mathrm{~cm}$ below LCM only. This resolved by the end of second year of ERT, so that none of the treated patients had splenomegaly at the end of the follow up period. In the untreated group, a greater percentage $(50 \%)$ of patients had palpable spleen up to $6.67 \mathrm{~cm}$, with progression in size by $4.83 \mathrm{~cm}$ in 6 patients.

\section{MWT}

Of the 40 patients, 13 were non-ambulatory, wheelchair-bound, all coming from untreated cohort. From the 27 ambulatory patients, only 2 treated patients had complete data throughout the 2-year follow-up period. One patient was seen to have a decline in the tolerated distance by $91.44 \mathrm{~m}$ from baseline to year 2 of follow up. While the other patient showed an improvement in the distance covered after 2 years of treatment by $172 \mathrm{~m}$. Nine untreated patients had data collected only on their 2nd year follow up, which showed below average distance covered. 


\section{Joint Mobility}

Thirteen out of the 40 patients had baseline data only and values indicate already existing joint limitations (Table 4). Only 7 patients had complete ROM data throughout the 2-year follow up period. There was an average of 10-20 degrees improvement of ROM mainly on the shoulders, hips and knees; with an average of 10-20 degrees worsening of joint mobility for elbow flexion and extension, ankle dorsiflexion and plantar flexion. In all, lower extremity joints were more likely to worsen compared to the upper extremity joints.

For the treated group, there was improvement in shoulder extension and internal rotation, elbow extension and pronation, wrist flexion and extension, and ankle plantarflexion, but with more limited knee flexion after 2 years of ERT. In the untreated cohort, improvement in joint mobility was seen in shoulder abduction, shoulder external rotation, knee flexion, and ankle dorsiflexion after 2 years. There was a decrease in mean ROM in shoulder flexion and extension, shoulder internal rotation, elbow flexion, elbow pronation, wrist flexion and extension, and ankle plantar flexion, indicating worsening of contractures in the untreated patients. 
Table 4

Mean change in ROM from baseline to 2 years for treated and untreated groups.

\begin{tabular}{|c|c|c|c|c|c|c|}
\hline & \multicolumn{3}{|c|}{ Treated $(n=8)$} & \multicolumn{3}{|c|}{ Untreated $(n=32)$} \\
\hline & $\begin{array}{l}\text { Baseline } \\
\left(\text { mean }^{\circ}\right)\end{array}$ & $\begin{array}{l}\text { Year } 2^{\circ} \\
\left(\text { mean }^{\circ}\right)\end{array}$ & Change* $^{*}\left(^{\circ}\right)$ & $\begin{array}{l}\text { Baseline } \\
\left(\text { mean }^{\circ}\right)\end{array}$ & $\begin{array}{l}\text { Year } 2 \\
\left(\text { mean }^{\circ}\right)\end{array}$ & Change* $^{*}\left(^{\circ}\right)$ \\
\hline Shoulder Flexion & 111 & 101 & -10 & 90.38 & 86.5 & -3.88 \\
\hline $\begin{array}{l}\text { Shoulder } \\
\text { Extension }\end{array}$ & 53.75 & 61.25 & 7.5 & 100 & 90 & -10 \\
\hline $\begin{array}{l}\text { Shoulder } \\
\text { Abduction }\end{array}$ & 99.13 & 98.4 & -0.725 & 85.63 & 87.78 & 2.15 \\
\hline $\begin{array}{l}\text { Shoulder Internal } \\
\text { Rotation }\end{array}$ & 55 & 67 & 12 & 40 & 30 & -10 \\
\hline $\begin{array}{l}\text { Shoulder External } \\
\text { Rotation }\end{array}$ & 52.5 & 59.25 & 6.75 & 35 & 40 & 5 \\
\hline Elbow Flexion & 93.13 & 89.5 & -3.63 & 109.17 & 104.83 & -4.33 \\
\hline Elbow Extension & 111 & -45 & 66 & -122.5 & -112.5 & 10 \\
\hline Elbow Supination & 10 & 10 & 0 & 80 & 80 & 0 \\
\hline Elbow Pronation & 35 & 55 & 20 & 80 & 62.5 & -17.5 \\
\hline Wrist Flexion & 46.2 & 32.5 & -13.7 & 33.75 & 6.25 & -27.5 \\
\hline Wrist Extension & 22.9 & 27.5 & 4.6 & 25 & 9.13 & -15.88 \\
\hline $\begin{array}{l}\text { Wrist Ulnar } \\
\text { Deviation }\end{array}$ & $\begin{array}{l}\text { No } \\
\text { information }\end{array}$ & $\begin{array}{l}\text { No } \\
\text { information }\end{array}$ & $\begin{array}{l}\text { No } \\
\text { information }\end{array}$ & 25 & 2.5 & -22.5 \\
\hline $\begin{array}{l}\text { Wrist Radial } \\
\text { Deviation }\end{array}$ & 25 & 20 & -5 & $\begin{array}{l}\text { No } \\
\text { information }\end{array}$ & $\begin{array}{l}\text { No } \\
\text { information }\end{array}$ & $\begin{array}{l}\text { No } \\
\text { information }\end{array}$ \\
\hline Hip Flexion & 126.08 & 108.83 & -17.25 & $\begin{array}{l}\text { No } \\
\text { information }\end{array}$ & $\begin{array}{l}\text { No } \\
\text { information }\end{array}$ & $\begin{array}{l}\text { No } \\
\text { information }\end{array}$ \\
\hline Hip Extension & 8.75 & 12.25 & 3.5 & $\begin{array}{l}\text { No } \\
\text { information }\end{array}$ & $\begin{array}{l}\text { No } \\
\text { information }\end{array}$ & $\begin{array}{l}\text { No } \\
\text { information }\end{array}$ \\
\hline Hip Abduction & 36.25 & 46.75 & 10.5 & $\begin{array}{l}\text { No } \\
\text { information }\end{array}$ & $\begin{array}{l}\text { No } \\
\text { information }\end{array}$ & $\begin{array}{l}\text { No } \\
\text { information }\end{array}$ \\
\hline $\begin{array}{l}\text { Hip Internal } \\
\text { Rotation }\end{array}$ & 42.5 & 39.5 & -3 & $\begin{array}{l}\text { No } \\
\text { information }\end{array}$ & $\begin{array}{l}\text { No } \\
\text { information }\end{array}$ & $\begin{array}{l}\text { No } \\
\text { information }\end{array}$ \\
\hline $\begin{array}{l}\text { Hip External } \\
\text { Rotation }\end{array}$ & 50 & 50.25 & 0.25 & $\begin{array}{l}\text { No } \\
\text { information }\end{array}$ & $\begin{array}{l}\text { No } \\
\text { information }\end{array}$ & $\begin{array}{l}\text { No } \\
\text { information }\end{array}$ \\
\hline Knee Flexion & 119.13 & 122.75 & 3.63 & 96.28 & 127.08 & 30.81 \\
\hline Knee Extension & 109.5 & -122.5 & -13 & $\begin{array}{l}\text { No } \\
\text { information }\end{array}$ & $\begin{array}{l}\text { No } \\
\text { information }\end{array}$ & $\begin{array}{l}\text { No } \\
\text { information }\end{array}$ \\
\hline
\end{tabular}

*Negative change in ROM: more limited joint mobility; positive change in ROM: improvement in mobility overtime. 


\begin{tabular}{|c|c|c|c|c|c|c|}
\hline \multirow[b]{2}{*}{ Ankle Dorsiflexion } & \multicolumn{3}{|c|}{ Treated $(n=8)$} & \multicolumn{3}{|c|}{ Untreated $(n=32)$} \\
\hline & 1.67 & 4.17 & 2.5 & 5 & 8.13 & 3.13 \\
\hline $\begin{array}{l}\text { Ankle } \\
\text { Plantarflexion }\end{array}$ & 37.33 & 38.38 & 1.04 & 40 & 27.5 & -12.5 \\
\hline Ankle Eversion & 5.5 & 3.75 & -1.75 & $\begin{array}{l}\text { No } \\
\text { information }\end{array}$ & $\begin{array}{l}\text { No } \\
\text { information }\end{array}$ & $\begin{array}{l}\text { No } \\
\text { information }\end{array}$ \\
\hline Ankle Inversion & 7.5 & 14 & 6.5 & $\begin{array}{l}\text { No } \\
\text { information }\end{array}$ & $\begin{array}{l}\text { No } \\
\text { information }\end{array}$ & $\begin{array}{l}\text { No } \\
\text { information }\end{array}$ \\
\hline
\end{tabular}

\section{Biochemical Profile}

Out of the 40 patients, 34 samples were measured as $\mathrm{nmol} / \mathrm{mg}$ plasma/ $4 \mathrm{~h}$ and the mean enzyme level was $0.53 \mathrm{nmol} / \mathrm{mg}$ plasma/4 h (SD 0.56; 0.01-2.34), while 5 samples were measured as uM/hr with mean of 0.12 (NV $>4.45 \mathrm{uM} / \mathrm{hr}$; SD $0.03 ; 0.09-0.17)$. The mean urinary GAG concentration for the 27 of the 40 patients was $525.96 \mathrm{mg} / \mathrm{g}$ creatinine (SD 204.35; 126.1-911.46). The urine GAGs were reported in separate components of HS and DS in 10 patients, with the following results: mean urinary HS of $35.87 \mathrm{ng} / \mathrm{ug}$ crea (SD $17.15 ; 14.85-58.4)$ and mean urinary DS $21.22 \mathrm{ng} / \mathrm{ug}$ crea (SD 15.38; 4.33-45.8).

In all, the biochemical profile did not show any correlation between level of plasma I2S activity and urinary GAGs concentration with clinical severity nor their age at diagnosis (Table 5). 
Table 5

Summary of Clinical and Biochemical Characteristics

\begin{tabular}{|c|c|c|c|c|c|c|c|c|c|}
\hline $\begin{array}{l}\mathrm{Pt} \\
\#\end{array}$ & $\begin{array}{l}\text { Age at } \\
\text { diagnosis } \\
\text { (years) }\end{array}$ & Phenotype & $\begin{array}{l}\text { Plasma } \\
\text { enzyme } \\
\text { (nmol/mg } \\
\text { plasma/4 h) }\end{array}$ & $\begin{array}{l}\text { Plasma } \\
\text { enzyme } \\
(>4.45 \\
\text { uM/hr) }\end{array}$ & $\begin{array}{l}\text { Urine } \\
\text { GAG } \\
\text { (mg/g } \\
\text { Crea) }\end{array}$ & $\begin{array}{l}\text { Urine } \\
\text { HS } \\
\text { (ng/ug } \\
\text { Crea) }\end{array}$ & $\begin{array}{l}\text { Urine } \\
\text { DS } \\
\text { (ng/ug } \\
\text { Crea) }\end{array}$ & $\begin{array}{l}\text { On } \\
\text { ERT }\end{array}$ & Outcome \\
\hline 1 & 1.8 & Severe & 0.01 & & 891.6 & & & Yes & Alive \\
\hline 2 & 3.75 & Severe & 0.17 & & & & & Yes & Alive \\
\hline 3 & 9 & Attenuated & 0.75 & & 363.3 & & & Yes & Alive \\
\hline 4 & 8 & Attenuated & 0.31 & & 629.73 & & & Yes & Alive \\
\hline 5 & 7 & Attenuated & 0.91 & & 302.04 & & & Yes & Alive \\
\hline 6 & 5 & Attenuated & 0.01 & & 443.76 & & & Yes & Alive \\
\hline 7 & 6 & Severe & 0.12 & & 567.6 & & & Yes & Alive \\
\hline 8 & 7 & Severe & 0.07 & & 690.65 & & & Yes & Alive \\
\hline 9 & 15 & Severe & 0.04 & & & 27.53 & 4.47 & No & Alive \\
\hline 10 & 10 & Attenuated & 0.31 & & 145.35 & & & No & Alive \\
\hline 11 & 0.58 & Severe & 0.26 & & 568.56 & & & No & Alive \\
\hline 12 & 10 & Severe & & 0.14 & & 44.27 & 41.98 & No & Alive \\
\hline 13 & 5 & Severe & 0.14 & & 759.98 & & & No & Alive \\
\hline 14 & 7 & Attenuated & 0.1 & & 683.36 & & & No & Alive \\
\hline 15 & 4 & Severe & 0.77 & & 376.06 & & & No & Alive \\
\hline 16 & 7 & Severe & & 0.17 & & 22.64 & 10.36 & No & Alive \\
\hline 17 & 4 & Severe & 0.07 & & & 42.28 & 4.33 & No & Alive \\
\hline 18 & 2 & Severe & 0.09 & & & 58.4 & 12.6 & No & Alive \\
\hline 19 & 23 & Attenuated & 0.34 & & & & & No & Alive \\
\hline 20 & 13 & Severe & 0.04 & & & 14.85 & 31.76 & No & Alive \\
\hline 21 & 9 & Severe & 0.06 & & & 20.8 & 45.8 & No & Alive \\
\hline 22 & 2.5 & Severe & & 0.11 & & 54.66 & 31.67 & No & Alive \\
\hline 23 & 3 & Severe & & 0.09 & & 53.13 & 21.42 & No & Alive \\
\hline 24 & 4 & Severe & 1.96 & & 339.87 & & & No & Alive \\
\hline 25 & 7 & Severe & & 0.11 & & 20.16 & 7.8 & No & Alive \\
\hline 26 & 5 & Severe & & & 472.73 & & & No & Alive \\
\hline 27 & 9 & Severe & 1.08 & & 626.57 & & & No & Alive \\
\hline 28 & 7 & Attenuated & 0.26 & & 692.59 & & & No & Deceased \\
\hline
\end{tabular}




\begin{tabular}{|c|c|c|c|c|c|c|c|c|c|}
\hline $\begin{array}{l}\text { Pt } \\
\#\end{array}$ & $\begin{array}{l}\text { Age at } \\
\text { diagnosis } \\
\text { (years) }\end{array}$ & Phenotype & $\begin{array}{l}\text { Plasma } \\
\text { enzyme } \\
\text { (nmol/mg } \\
\text { plasma } / 4 \mathrm{~h} \text { ) }\end{array}$ & $\begin{array}{l}\text { Plasma } \\
\text { enzyme } \\
(>4.45 \\
\mathrm{uM} / \mathrm{hr})\end{array}$ & $\begin{array}{l}\text { Urine } \\
\text { GAG } \\
\text { (mg/g } \\
\text { Crea) }\end{array}$ & $\begin{array}{l}\text { Urine } \\
\text { HS } \\
\text { (ng/ug } \\
\text { Crea) }\end{array}$ & $\begin{array}{l}\text { Urine } \\
\text { DS } \\
\text { (ng/ug } \\
\text { Crea) }\end{array}$ & $\begin{array}{l}\text { On } \\
\text { ERT }\end{array}$ & Outcome \\
\hline 29 & 3 & Severe & 0.93 & & 485.0509 & & & No & Deceased \\
\hline 30 & 7 & Severe & 0.53 & & & & & No & Deceased \\
\hline 31 & 7 & Severe & 0.742 & & 778.6195 & & & No & Deceased \\
\hline 32 & 5 & Severe & 1.1 & & 238.0952 & & & No & Deceased \\
\hline 33 & 6 & Severe & 1.08 & & 126.1 & & & No & Deceased \\
\hline 34 & 7 & Severe & 0.1 & & 284.49 & & & No & Deceased \\
\hline 35 & 14 & Severe & 0.94 & & 743.35 & & & No & Deceased \\
\hline 36 & 8 & Severe & 0.63 & & 477.76 & & & No & Deceased \\
\hline 37 & 4 & Severe & 0.525 & & 911.4583 & & & No & Deceased \\
\hline 38 & 6 & Severe & 2.34 & & 535.221 & & & No & Deceased \\
\hline 39 & 12 & Severe & 1.15 & & 549.65 & & & No & Deceased \\
\hline 40 & 6 & Severe & 0.01 & & 517.45 & & & No & Deceased \\
\hline
\end{tabular}

\section{Mortality}

At the time of review, 13 of the 40 (32.5\%) have died, all coming from the untreated cohort. Majority (12/13; $92.3 \%)$ of the deceased patients were diagnosed with moderate to severe cognitive impairment, with only 1 patient diagnosed with mild ID. The mean age at death was 15.22 years old (SD 2.72; range 11.75 to 19). Pulmonary or cardiac causes were the only causes of death, with $11 / 13$ (84.61\%) deaths attributed to complications from pneumonia and 2/13 (15.39\%) deaths due to progression of underlying cardiac disease.

\section{Safety profile}

Initially, there were 9 patients who started ERT in the Philippines. Of the 9, 4 had infusion-related reactions (IRRs), manifesting as anaphylaxis in 1 patient $(11.11 \%)$ and urticarial rash in $3 / 9(33.33 \%)$ patients. There were no nonIRRs recorded in the treatment group.

\section{Discussion}

The first manuscript that described the clinical, biochemical and molecular characteristics of 23 Filipino patients with Hunter syndrome was published in 2017. ${ }^{13}$ Since then, around 36 more patients were diagnosed and listed in our local LSD registry, and ERT with IDS was started in 9 patients. This study is a follow-up to that, describing the clinical outcomes in two subsets of MPS II patients - idursulfase-treated and untreated. Although there are inherent limitations in this study - including lack of more objective and standardized diagnostic assessments, variation in number of patients from baseline to each follow up period and the limited number of patients that precludes statistically significant comparison - it still provides valuable insight into the effects of therapy among our Filipino cohort. In general, ERT seems effective in reducing GAG storage as evidenced by resolution of 
hepatosplenomegaly, and results to a general trend of improvement in clinical endpoints such as growth, respiratory involvement, cardiac disease, joint ROM, and mortality rate.

This more recent data shows that the mean age at diagnosis remains at 7 years old, with delay of almost 5 years from symptom onset to biochemical confirmation. Compared to data from $\mathrm{HOS}^{6}$ and the UK study, ${ }^{5}$ where the mean ages at diagnosis were 1.5 and 1.2 years, respectively, there is significant delay among Filipino patients. The same reasons cited by Chiong et al, such as late recognition of this multi-system disorder and inadequate health system infrastructure and referral system, still hold true. ${ }^{13}$ The early clinical manifestations among our cohort are consistent with previous reports, which were observed by the caregivers at an average of 2 years old. The data suggest that early recognition by caregivers need to be promoted, alongside education of primary care physicians on rare diseases.

All patients in this review were biochemically-confirmed. Urinary GAGs concentration did not show any correlation with age at diagnosis, while plasma I2S level was not predictive of clinical severity, which is in keeping with previous findings. ${ }^{13}$

Management guidelines for the treatment of Filipinos with MPS II recommend ERT for any patient with a documented biochemical diagnosis, without severe cognitive impairment, and with at least one clinical manifestation that is still deemed treatable and not too far advanced to be addressed by ERT. ${ }^{14}$ However, due to the prohibitive cost of enzyme plus the lack of government funding for orphan drugs, only 5 patients could qualify to receive ERT via Sanofi Genzyme's International Charitable Access Program (ICAP). Two more siblings were able to start ERT through support from the Department of Health. However, the funding could only sustain treatment for 10 months. Two more patients were started on IDS under an ongoing multi-center experimental study. They were both assessed with severe cognitive impairment and were started on therapy at a mean age of 4.7 years. Overall, the mean age at start of treatment for our cohort was 14 years old, which is considerably later than their counterparts according to HOS, whose age at first treatment was 6.2 years old. ${ }^{6}$

Short stature is a well-known feature of MPS II and is most evident after 8 years old. ${ }^{15}$ Prior to this, height was observed to remain within normal range and even showed faster growth rates. ${ }^{15,16}$ However, this distinctive growth pattern was not apparent in our Filipino cohort, wherein $32 \%$ of patients 8 years and below were already found to be stunted (58\% were within normal and the remaining $10 \%$ taller than their normal peers). This may be due to ethnic differences and could be evaluated further by correlating with their respective mid-parental heights. As the patients age, height seem to slow down more considerably compared to unaffected peers as evidenced by lower mean increase in height and more percentage of stunted patients in the older than in younger age group. This also suggests that Filipino patients are unable to mount an adequate pubertal growth spurt, as expected, although growth velocity will give a more precise information. Consistent with published reports. ${ }^{12,15}$ ERT has a positive effect on linear growth since treated patients had a greater increase in height than untreated age-matched patients.

Natural history data shows that MPS II patients tend to be heavier than their unaffected peers until 9 years old, and their BMI remain high until 14-16 years. ${ }^{16}$ But this pattern was also not observed among our cohort since only $15 \%$ of patients in that age group were recorded to be overweight (WHO z score above +2$)$, although body mass index would be a better indicator. Data on the effect of ERT on weight is more limited, and has only been studied by Tomanin et al. ${ }^{17}$ Similar to their analysis, our data suggests a negative trend for weight among untreated patients as there is greater percentage of underweight patients recorded in the older, untreated age group. Since the treated

Page $15 / 24$ 
cohort demonstrated greater total weight gain compared with untreated group, it further supports mitigation of the negative effect on overall growth by ERT. Moreover, some untreated patients were found to have regression in growth (ie. shorter or lighter) at the end of the study period. These may be attributed to progression of joint contractures leading to decreases in height measurements, poor nutrition due to progression of somatic symptoms leading to emaciation, ${ }^{18}$ or simply interobserver variability. Several factors, such as age at start of ERT, type of mutation, and cognitive impairment, were found to impact growth parameters, ${ }^{12,15}$ but their correlation remains to be explored among our Filipino Hunter syndrome patients.

The neurocognitive phenotype of MPS II is more heterogenous than previously thought ${ }^{5}$ and needs further research among our patients. But according to the traditional binary classification, $80 \%$ of our patients fall within the early progressive or severe type, which is higher that the reported $61.5 \%$ from HOS. ${ }^{6}$

Respiratory compromise is present in majority of our patients, as expected, most commonly presenting as OSA. The progression of airway obstruction seem more relentless in the untreated group as there is a higher absolute number of patients needing positive pressure assistance and tracheostomy coming from this cohort. Since FVC, the more objective parameter to assess pulmonary function in MPS II patients, ${ }^{4}$ is not part of our routine monitoring, we cannot definitely determine whether ERT has any impact on respiratory function. Needless to say, this is worth looking into because improved pulmonary function would in turn lead to better growth, endurance, and survival. 4

Our findings on the positive effects of ERT on cardiac function are in keeping with published reports, ${ }^{5,6,8}$ notably improvement in left ventricular dimensions. With regards its effect on valvular disease, more data from our cohort is needed. As expected of the natural course of MPS II, there was progression of cardiac disease when left untreated, evident in about half of our untreated cohort after 2 years.

Hepatosplenomegaly based on palpation was evident among our cohort, with liver more affected than spleen. Consistent with reports from $\mathrm{HOS}^{6}$ and Japan Elaprase Treatment (JET) study, ${ }^{8}$ ERT is effective in reducing the liver and spleen sizes, with continued improvement observed at year 1 and year 2 of follow up. This data suggests that ERT is indeed effective in reducing GAG storage, however routine urinary GAG measurement and abdominal magnetic resonance imaging or ultrasound will provide a more accurate information. ${ }^{6}$

We have limited data to describe the effects of ERT on 6MWT. However, as expected, our untreated cohort have suboptimal results reflected by below average distance covered recorded during follow up. Data on joint mobility is hard to interpret because of heterogenous patient characteristics and measurements. ${ }^{6}$ For these reasons, only the JET study has shown evidence of joint mobility improvement with ERT (albeit not statistically significant) thus far. ${ }^{8}$ While our data is limited and is confounded by interobserver variability, it suggests a positive impact of idursulfase treatment on joint mobility based on higher degree of improvement on more joints after 2 years of ERT. Moreover, worsening of ROM was observed on more joints in untreated cohort on follow up. Overall, our physical rehabilitation data underscores the need to consistently include 6MWT and joint ROM during follow up of MPS II patients. In particular, 6MWT is very informative because it is an integrated assessment of cardiac, respiratory, and musculoskeletal functions. ${ }^{4}$ It also emphasizes that ERT should be coupled with consistent rehabilitation follow up and motivation of caregivers towards chronic illness, in order to have a more significant improvement in the functional outcomes of these patients. 
Perhaps one of the most significant benefits of ERT is on patient survival, as documented by Burton et. al. ${ }^{9}$ Although our sample size is mathematically small, it is still worth noting that all patients undergoing ERT are still alive at the time of review at a mean age of 16.14 years. Deceased patients succumbed on the second decade of life, most commonly as a result of pulmonary infection, which is the typical course for untreated patients. ${ }^{19-21} \mathrm{~A}$ higher degree of cognitive impairment is associated with increased mortality, ${ }^{9}$ which may explain why all but one of our deceased patients were categorized under the severe phenotype.

In our cohort, only IRRs were reported in majority, classified as mild in most cases with only one severe AE. The anaphylactic reaction was successfully managed outside of the ICU-setting. Recurrence of urticarial reactions was not observed, most likely due to premedication with antihistamine and/or corticosteroids and a 3-hour infusion time. It has been suggested that IRR rates were higher in patients who were found to have developed antibodies, ${ }^{22}$ therefore determination of antibody formation may provide more information on the safety and efficacy of ERT among our local cohort.

In conclusion, ERT is generally well-tolerated and effective in reducing GAG storage and improving clinical endpoints among our Filipino MPS II patients. Meanwhile, natural disease progression was observed in our untreated patients. As these treated patients are expected to receive long-term ERT, more objective studies, standardized assessments, as well as upkeep of the LSD registry should be undertaken in order to more accurately monitor the overall effect of therapy. It would also be interesting to evaluate the psychosocial impact of ERT in terms of amelioration of somatic symptoms juxtaposed against the burden of weekly injections. That being said, supportive measures remain to be standard of care for majority of our MPS II patients due to the prohibitive cost of idursulfase. Holistic well-being of our patients, therefore, will depend on continued supervision by a multidisciplinary team of experts, in partnership with committed caregivers and support from national health department.

\section{Declarations}

\section{Ethics approval and consent to participate}

Waiver of informed consent was applied since the retrospective method of data collection would entail not more than minimal risk. The study protocol was approved by UPM Research Ethics Board (2020-108-01).

\section{Consent for publication}

Not applicable.

\section{Availability of data and materials}

The datasets generated and/or analyzed during the current study are not publicly available because they are protected by the Data Privacy Act Data Privacy Act of 2012 (Republic Act 10173), but are available from the corresponding author on reasonable request.

\section{Competing interests}

We are reporting that MADC and MARA are co-investigators for LSD Registry Project in the Philippines (Genzyme), and both are also co-investigators for on-going clinical trial SHP-ELA-401 (Shire) entitled, "A Long-Term, Open- 
Label, Multicenter, Phase IV Study to Assess Longitudinal Changes on Height and Weight in Patients with MPS II Who Are Receiving Elaprase and Started Treatment with Elaprase at < 6 years of age."

\section{Funding}

This was self-funded by the primary author.

\section{Authors' contributions}

MJCR wrote the manuscript, collected, analyzed and interpreted the patient data. MKKC analyzed and interpreted the data regarding rehabilitation parameters, and contributed to manuscript writing. All authors contributed to the conception of this research, data analysis, then read and approved the final manuscript.

\section{Acknowledgements}

The authors would like to extend their gratitude to the Institute of Human Genetics, National Institutes of Health, UP Manila, for giving us access to the LSD registry. Many thanks to the Philippine Society of Orphan Disorders (PSOD) and MPS multidisciplinary team at the Philippine General Hospital for their dedication in the care of these patients.

\section{References}

1. Scarpa M, Almássy Z, Beck M, Bodamer O, Bruce IA, De Meirleir L, Guffon N, Guillén-Navarro E, Hensman $P$, Jones S, Kamin W, Kampmann C, Lampe C, Lavery CA, Teles EL, Link B, Lund AM, Malm G, Pitz S, Rothera M, Stewart C, Tylki-Szymańska A, van der Ploeg A, Walker R, Zeman J, Wraith JE. Hunter Syndrome European Expert Council. Mucopolysaccharidosis type II: European recommendations for the diagnosis and multidisciplinary management of a rare disease. Orphanet J Rare Dis. 2011;6:72. PubMed PMID: 22059643.

2. Jones S, Wijburg F. Mucopolysaccharidoses, Oligosaccharidoses and Sialic Acid Disorders. In: Saudubray JM, Walter JH, Baumgartner MR, eds. Inborn metabolic diseases: diagnosis and treatment, $6^{\text {th }}$ Berlin: Springer; 2016. pp. 579-584.

3. Stapleton M, Kubaski F, Mason R, Yabe H, Suzuki Y, Orii K et al. Presentation and treatments for Mucopolysaccharidosis Type II (MPS II; Hunter Syndrome). Expert Opinion on Orphan Drugs. 2017;5(4):295307.

4. Sestito S, Concolino D, Ceravolo F, Grisolia M, Pascale E, Pensabene L. Profile of idursulfase for the treatment of Hunter syndrome. Research and Reports in Endocrine Disorders.2015. 5: 79-90.

5. Broomfield A, Davison J, Roberts J, Stewart C, Hensman P, Beesley C, Tylee K, Rust S, Schwahn B, Jameson E, Vijay S, Santra S, Sreekantam S, Ramaswami U, Chakrapani A, Raiman J, Cleary M, Jones S. Ten years of enzyme replacement therapy in paediatric onset mucopolysaccharidosis II in England. Molecular Genetics and Metabolism 2020 ; 129: 98-105.

6. Muenzer J, Giugliani R, Scarpa M, Tylki-Szymańska A, Jego V, Beck M. Clinical outcomes in idursulfase-treated patients with mucopolysaccharidosis type II: 3-year data from the hunter outcome survey (HOS). Orphanet Journal of Rare Diseases 2017; 12: 161

7. Lampe C, Bosserhoff A, Burton B, Giugliani R, de Souza C, Bittar C, Muschol N, Olson R, Mendelsohn N. Longterm experience with enzyme replacement therapy (ERT) in MPS II patients with a severe phenotype: an international case series. Journal of Inherited Metabolic Disease 2014 ; 37: 823-829. 
8. Okuyama T, Tanaka A, Suzuki Y, Ida H, Tanaka T, Cox G et al. Japan Elaprase® Treatment (JET) study: Idursulfase enzyme replacement therapy in adult patients with attenuated Hunter syndrome (Mucopolysaccharidosis II, MPS II). Molecular Genetics and Metabolism. 2010;99(1):18-25.

9. Burton B, Jego V, Mikl J, Jones S. Survival in idursulfase-treated and untreated patients with mucopolysaccharidosis type II: data from the Hunter Outcome Survey (HOS). Journal of Inherited Metabolic Disease 2017 ; 40: 867-874.

10. Faner M, Chiong MD. Clinical Profiles and Outcomes of the Most Common Inherited Metabolic Diseases in the Philippines: A Review of the National Institutes of Health - Institute of Human Genetics Metabolic Registry. Acta Medica Philippina. 2020;54(3): 236-243.

11. Tan I, Gajra B, Lim Study of inherited metabolic disorders in Singapore - 13 years experience. Ann Acad Med Singapore. 2006; 35(11):804-13.

12. Cho S, Huh R, Chang M, Lee J, Kwun Y, Maeng S, Kim S, Sohn Y, Park S, Kwon E, Han S, Jung J, Jin D. Impact of Enzyme Replacement Therapy on Linear Growth in Korean Patients with Mucopolysaccharidosis Type II (Hunter Syndrome). 2020

13. Chiong M, Canson D, Abacan M, Baluyot M, Cordero C, Silao C. Clinical, biochemical and molecular characteristics of Filipino patients with mucopolysaccharidosis type II - Hunter syndrome. Orphanet Journal of Rare Diseases $2017 ; 12: 7$

14. Abacan MAR, Chiong MAD. Treatment Guidelines for Filipino MPS Patients. (unpublished). 2013

15. Jones S, Parini R, Harmatz P, Giugliani R, Fang J, Mendelsohn N. The effect of idursulfase on growth in patients with Hunter syndrome: Data from the Hunter Outcome Survey (HOS). Molecular Genetics and Metabolism. 2013; 109: 41-48

16. Parini R, Jones S, Harmatz P, Giugliani R, Mendelsohn N. The natural history of growth in patients with Hunter syndrome: Data from the Hunter Outcome Survey (HOS). Molecular Genetics and Metabolism. 2016; 117: 438-446

17. Tomanin R, Zanetti A, D’Avanzo F, Rampazzo A, Gasparotto N, Parini R, Pascarella A, Concolino D, Procopio E, Fiumara A, Borgo A, Frigo A, Scarpa M. Clinical efficacy of Enzyme Replacement Therapy in paediatric Hunter patients, an independent study of 3.5 years. Orphanet Journal of Rare Diseases 2014; 9:129.

18. Young ID, Harper PS. The natural history of the severe form of Hunter's syndrome: a study based on 52 cases. Dev Med Child Neurol. 1983; 25: 481-9.

19. Neufeld E, Muenzer J. The mucopolysaccharidoses. In: Schriver CR, Beaudet AL, Sly WS, Valle D, eds. Themetabolic and molecular bases of inherited disease. New York: McGraw-Hill; 2001: 3421-52.

20. Wraith J, Scarpa M, Beck M, Bodamer O, De Meirleir L, Guffon N, Meldgaard Lund A, Malm G, Van der Ploeg A, Zeman J. Mucopolysaccharidosis type II (Hunter syndrome): a clinical review and recommendations for treatment in the era of enzyme replacement therapy. European Journal of Pediatrics. 2007; 167: 267-277.

21. Jones S, Almássy Z, Beck M, Burt K, Clarke J, Giugliani R, Hendriksz C, Kroepfl T, Lavery L, Lin S, Malm G, Ramaswami U, Tincheva R, Wraith J. Mortality and cause of death in mucopolysaccharidosis type II-a historical review based on data from the Hunter Outcome Survey (HOS). Journal of Inherited Metabolic Disease. 2009; 32: 534-543.

22. Barbier AJ, Bielefeld B, Whiteman DA, Natarajan M, Pano A, Amato DA. The relationship between antiidursulfase antibody status and safety and efficacy outcomes in attenuated mucopolysaccharidosis II patients aged 5 years and older treated with intravenous idursulfase. Mol Genet Metab. 2013;110(3):303-310. 


\section{Figures}

(A)

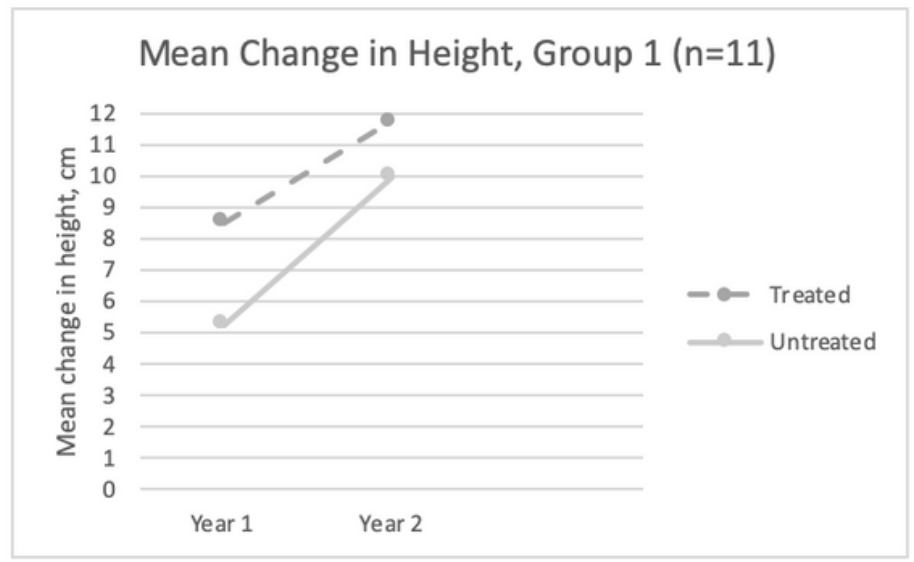

(B)

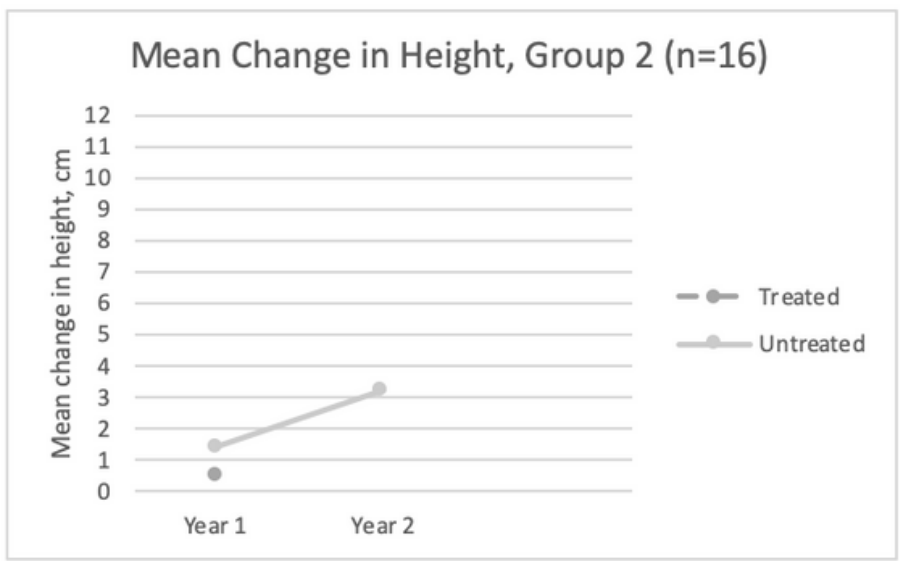

(C)

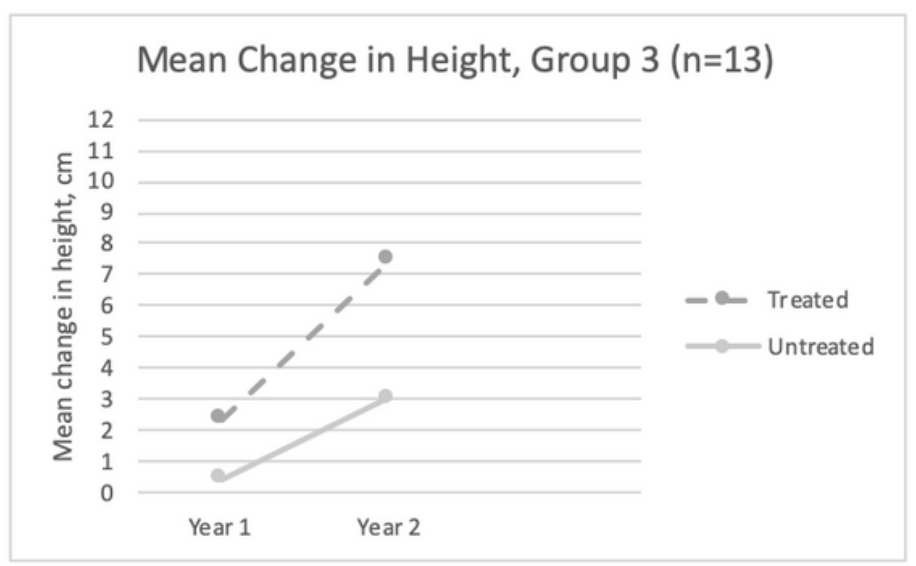

\section{Figure 1}

Mean annual change in height for treated and untreated MPS II patients at year 1 and year 2 of follow up as classified in to age groups. (A) Group 1: aged <6 years at start of ERT or at time of diagnosis, (B) Group 2: aged 610 years at start of ERT or at time of diagnosis (C) Group 3: aged >10 years at start of ERT or at time of diagnosis. 
(A)

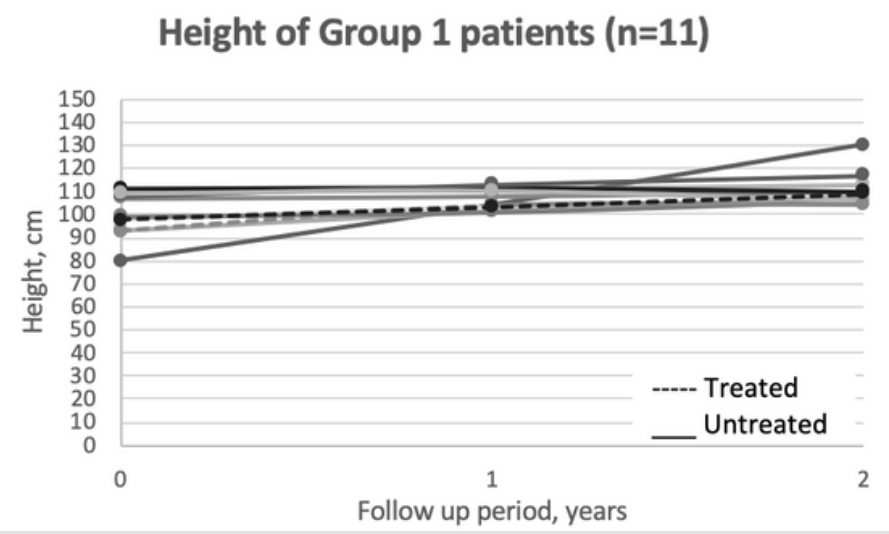

(C)

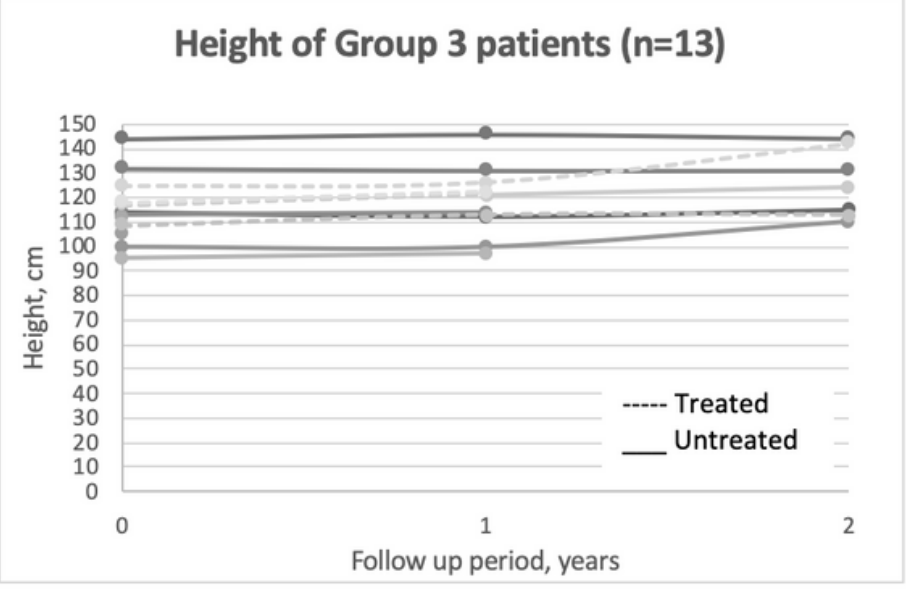

(B)

Height of Group 2 patients $(n=16)$

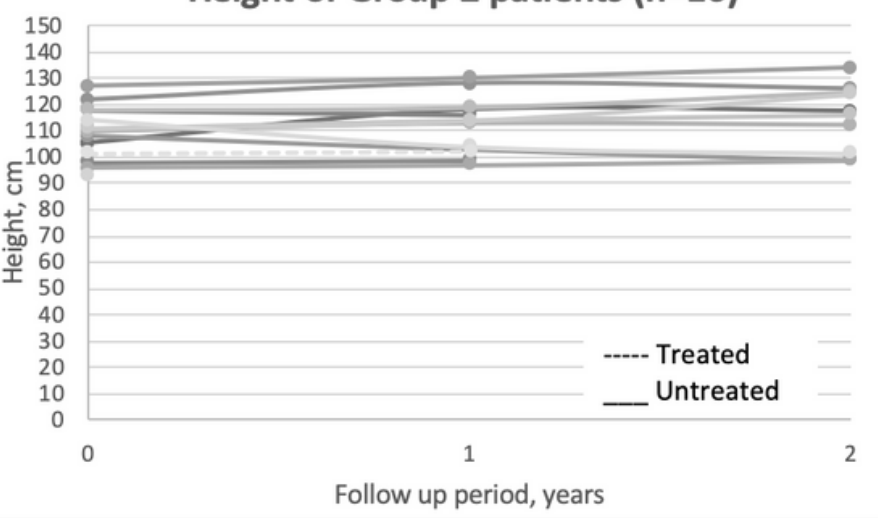

\section{Figure 2}

Height of treated and untreated MPS II patients at baseline (0) year 1 and year 2 of follow up as classified in to age groups. (A) Group 1: aged <6 years at start of ERT or at time of diagnosis, (B) Group 2: aged 6-10 years at start of ERT or at time of diagnosis (C) Group 3: aged >10 years at start of ERT or at time of diagnosis. 
(A)

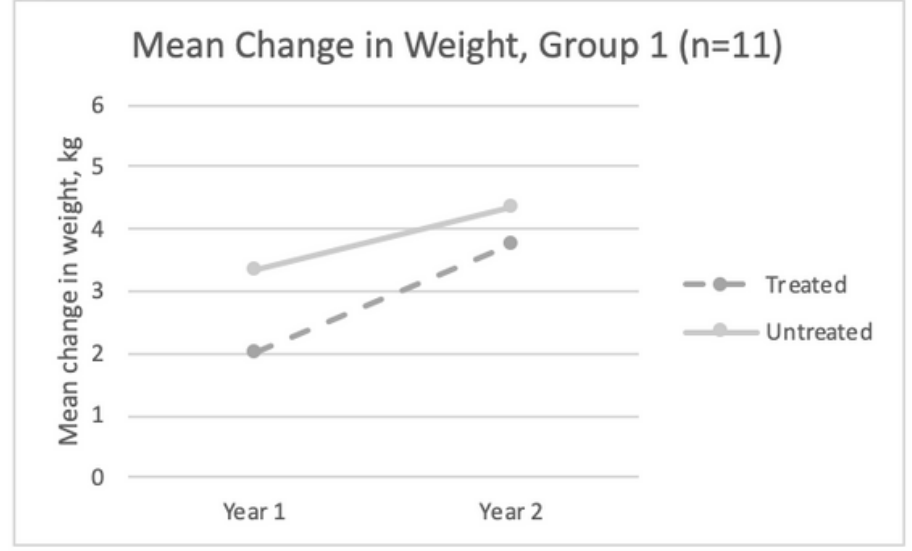

(B)

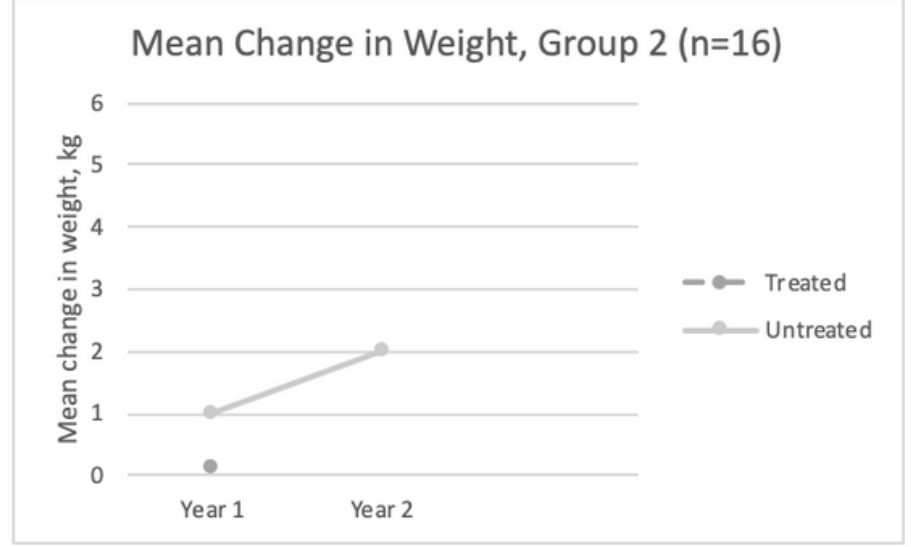

(C)

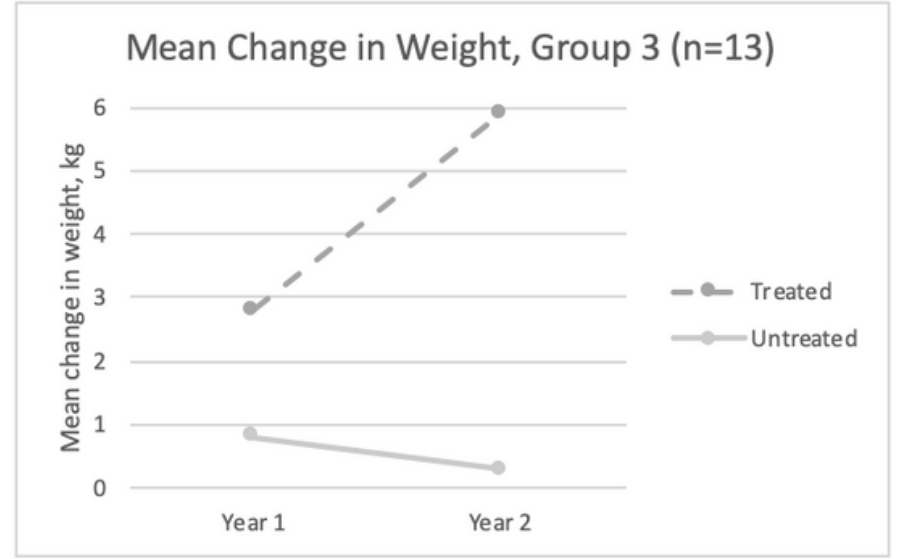

\section{Figure 3}

Mean annual change in weight for treated and untreated MPS II patients at year 1 and year 2 of follow up as classified in to age groups. (A) Group 1: aged $<6$ years at start of ERT or at time of diagnosis, (B) Group 2: aged 610 years at start of ERT or at time of diagnosis (C) Group 3: aged >10 years at start of ERT or at time of diagnosis. 
(A)

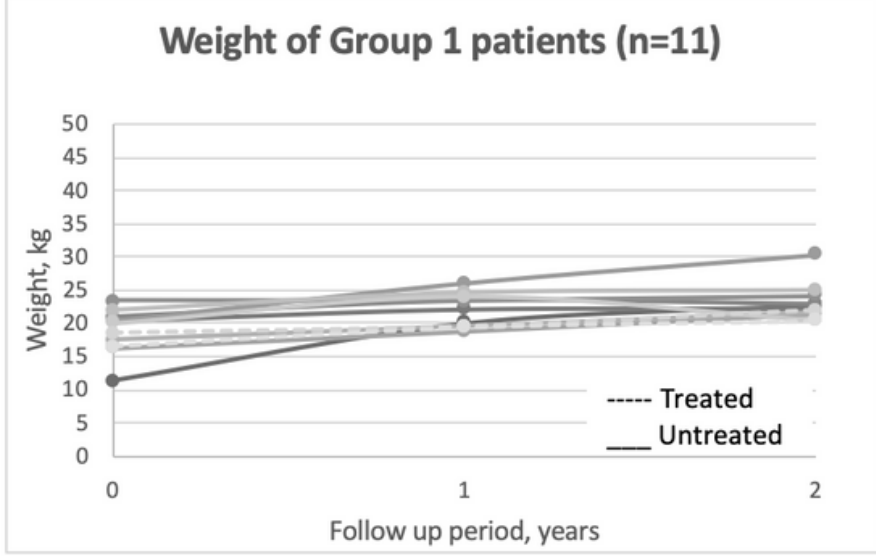

(C)

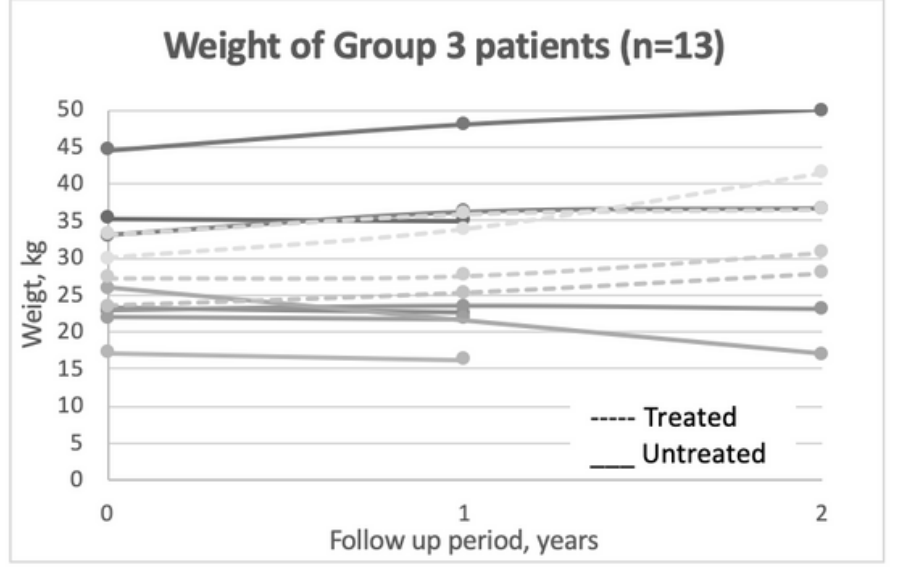

(B)

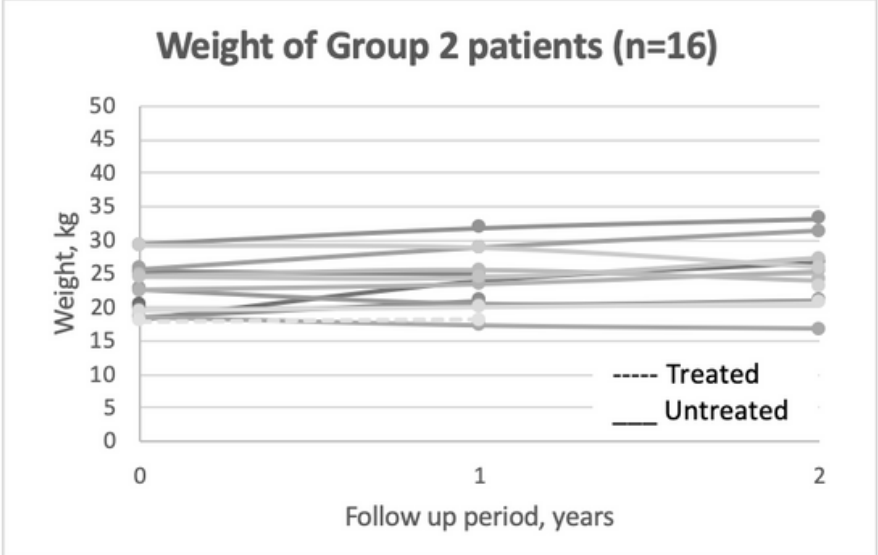

\section{Figure 4}

Weight of treated and untreated MPS II patients at baseline (0) year 1 and year 2 of follow up as classified in to age groups. (A) Group 1: aged $<6$ years at start of ERT or at time of diagnosis, (B) Group 2: aged 6-10 years at start of ERT or at time of diagnosis (C) Group 3: aged $>10$ years at start of ERT or at time of diagnosis. 


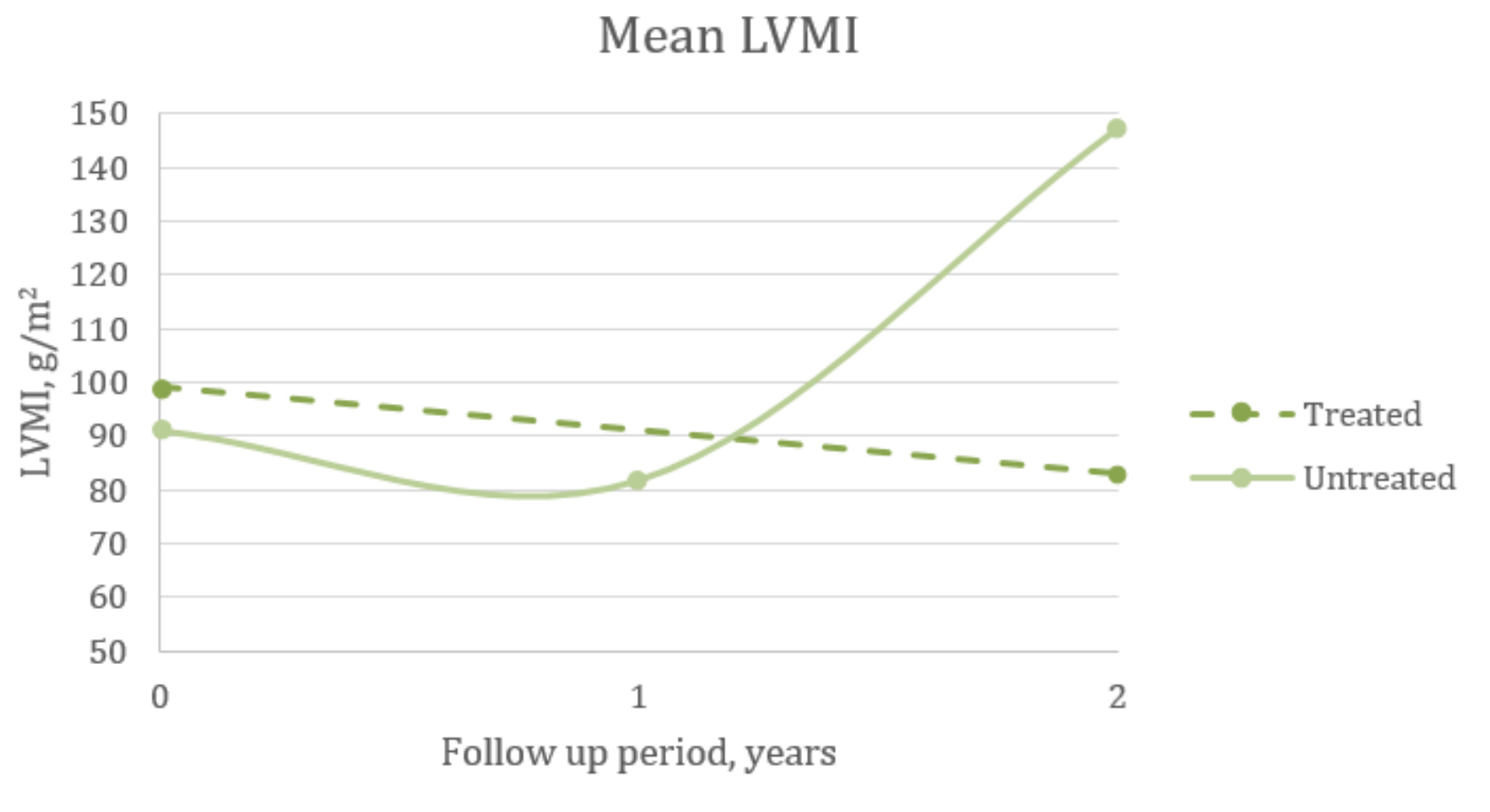

\section{Figure 5}

Mean LVMI in $\mathrm{g} / \mathrm{m} 2$ as measured by $2 \mathrm{~d}$ echocardiogram, according to treatment group. Baseline $\mathrm{n}=17$ (Treated=5, Untreated=12), year $1 \mathrm{n}=5$ (treated=no information available, untreated $=5)$, and year $2 \mathrm{n}=6$ (treated=3, untreated=3). 